EGG- -2146

DE82. 012769

\title{
GEOTHERMAL FEASIBILITY-ANALYSIS II FOR POLO SCHOOL DISTRICT \#29-2, SOUTH DAKOTA
}

\author{
Published March 1982 \\ Hengel Associates
115 St. Joseph Street \\ Rapid City, South Dakota
}

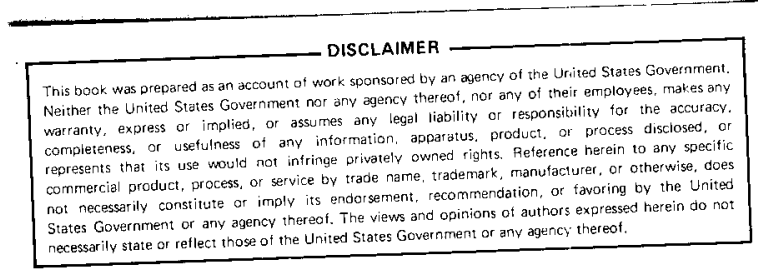

Prepared for EG\&G Idaho, Inc.

Under Subcontract No. P950061, Modification No. P643536 and the U.S. Department of Energy Idaho Operations Office Under DOE Contract No. DE-AC07-76ID01570 


\section{DISCLAIMER}

This report was prepared as an account of work sponsored by an agency of the United States Government. Neither the United States Government nor any agency Thereof, nor any of their employees, makes any warranty, express or implied, or assumes any legal liability or responsibility for the accuracy, completeness, or usefulness of any information, apparatus, product, or process disclosed, or represents that its use would not infringe privately owned rights. Reference herein to any specific commercial product, process, or service by trade name, trademark, manufacturer, or otherwise does not necessarily constitute or imply its endorsement, recommendation, or favoring by the United States Government or any agency thereof. The views and opinions of authors expressed herein do not necessarily state or reflect those of the United States Government or any agency thereof. 


\section{DISCLAIMER}

Portions of this document may be illegible in electronic image products. Images are produced from the best available original document. 


\section{PREFACE}

This report was prepared for EG\&G Idaho by Hengel Associates on Subcontract No. P950061, Modification No. P643536, under the Department of Energy's Outreach Program. It is being reissued as an EG\&G formal report in order to make it available to others who may be interested in this geothermal application. 


\section{FOREWORD}

The Geothermal Technical Assistance Program was developed under the premise that the majority of groups or individuals with available geothermal resources do not have the experience or manpower necessary to do a preliminary engineering and economic feasibility evaluation for geothermal energy projects. In order to disseminate technical information and to facilitate expanded use of geothermal energy resources, assistance was provided through FY-1981 in a consulting format on a first-come, staff-andfunds-available basis. Technical assistance can relate to conceptualization; engineering; economics; water chemistry implications for environmental, disposal, and material selection considerations; and planning and development strategies. This report is one of a series adapted from consultation provided to requesters either through in-house efforts or through limited efforts subcontracted to local engineering firms. The Geothermal Technical Assistance (GTA) Reports in this series, which are listed below, will be available for purchase early in 1982 by those with interest in specific geothermal applications from the U.S. National Technical Information Service:

U.S. Department of Commerce, National Technical Information Service, 5285 Port Royal Road, Springfield, VA 22161, (703) $557-4650$

GTA

$\underline{\text { Report Number }}$

1.

2.

3.

4.

5.

6.

7.

8.

9.

*EGG-2138
EGG-GTH-5617

*EGG-2137

EG\&G

Report Number

*EGG-GTH-5512

*EGG-GTH-5521

*EGG-GTH-5573

*EGG-GTH-5574

*EGG-GTH-5575

*EGG-GTH-5599$$
\text { -2137 }
$$

Title

Aquaculture Facility Potential at Boulder Hot Springs, Boulder, Montana

Preliminary Geothermal Disposal Considerations, State Health Laboratory, Boise, Idaho

Geothermal Conversion at Veterans Hospital, Boise, Idaho

Geothermal Applications for Highway Rest Areas

Geothermal Applications for a Tannery

Preliminary Conceptual Design for Geothermal Space Heating Conversion of School District SO Joint Facilities at Pagosa Springs, Colorado

Selected Geothermal Technical Assistance Efforts (comprising short descriptions of ten space heating projects, five district heating projects, and three heat exchanger projects)

Geothermal Source Potential and Utilization for Methane Generation and Alcohol Production (subcontractor report)

Geothermal Source Potential and Utilization for Alcohol Production (subcontractor report) 
GTA

Report Number

10.

11.

12.

*EGG-2145

13.

14.

EGG-2147

15.

*EGG-2148

16.

17.

18.

19.

20.

21.

22.

23.

EGG-2156

24.

25.

*EGG-GTH-5739

*EGG-GTH-5740
Title

Potential Geothermal Energy Applications for Idaho Elks Rehabilitation Hospital (subcontractor report)

Technical Assistance Report on a Geothermal Heating Utility for Lemmon, South Dakota (subcontractor report)

Economic Analysis for Utilization of Geothermal Energy by North Dakota Concrete Products Company (subcontractor report)

Geothermal Feasibility Analysis II for Polo School District No. 29-2, South Dakota (subcontractor report)

Preliminary Feasibility Study of Heating and Cooling Alternatives for Nebraska Western College, Scottsbluff, Nebraska (subcontractor report)

Inventory of Thermal Springs and Wells Within a OneMile Radius of Yucca Lodge, Truth or Consequences, New Mexico (subcontractor report)

Space Heating for Spa Facilities at Ojo Caliente, New Mexico (subcontractor report)

Space Heating for Office Building at Glenwood Springs, Colorado (subcontractor report)

District Heating for Subdivision in Dickinson, North Dakota (subcontractor report)

Space Heating for Subdivision in Truth or Consequences, New Mexico (subcontractor report)

Space Heating for Veterans Administration Medical Center, Marlin, Texas (subcontractor report)

District Heating for Subdivision in Castle Rock, Colorado (subcontractor report)

Space Heating for Twin Lakes School Near Gallup, New Mexico (subcontractor report)

Pumping Tests of Well Campbell Et Al. No. 2, Gila Hot Springs, Grant County, New Mexico (subcontractor report)

Geothermal Deicing of Bridge Structures

Assessment of a Geothermal Application at Tucson, Arizona 


\begin{tabular}{|c|c|c|}
\hline $\begin{array}{c}\text { GTA } \\
\text { Report Number }\end{array}$ & $\begin{array}{c}\text { EG\&G } \\
\text { Report Number }\end{array}$ & Title \\
\hline 26. & *EGG-GTH-5741 & Heat Pump Systems for Spring Creek, Montana \\
\hline 27. & EGG-GTH-5779 & Pipe Selection Guide \\
\hline 28. & EGG-GTH-5804 & $\begin{array}{l}\text { An Overview of Engineering and Agricultural Design } \\
\text { Considerations of the Raft River Soil-Warming and } \\
\text { Heat-Dissipation Experiment }\end{array}$ \\
\hline 29. & EGG-GTH-5812 & $\begin{array}{l}\text { Design of the Glenwood Springs Downhole Heat } \\
\text { Exchanger }\end{array}$ \\
\hline
\end{tabular}

*Published as of $3 / 15 / 82$. 
GEOTHERMAL FEASIBILITY ANALYSIS II

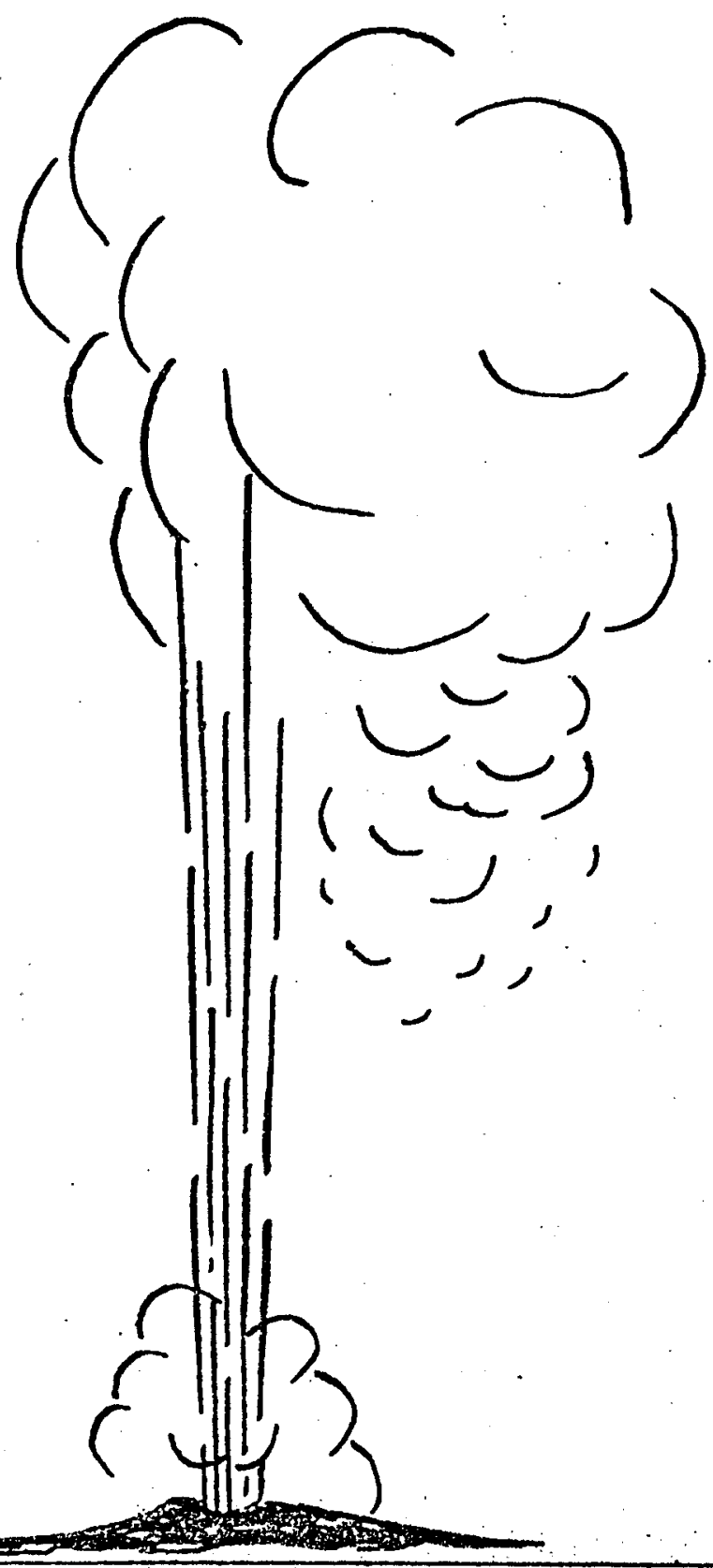

FOR POLO SCHOOL DISTRICT \#29-2

EG\&G SUBCONTRACT NO. P950061

MODIFYING NO. P643536

FINAL REPORT

MARCH 1982

PREPARED BY

HENGEL ASSOCIATES

ARCHITECTS - ENGINEERS

115 ST. JOSEPH STREET

RAPID CITY, SOUTH DAKOTA

\section{U. S. DEPARTMENT OF ENERGY Geothermal Energy}


Permission is hereby given to reprint this report with the following disclaimer:

THIS REPORT WAS PREPARED TO DOCUMENT WORK SPONSORED BY THE UNITED STATES GOVERNMENT. NEITHER THE UNITED STATES NOR ITS AGENT, THE UNITED STATES DEPARTMENT OF ENERGY, NOR ANY FEDERAL EMPLOYEES, NOR ANY OF THEIR CONTRACTORS, SUBCONTRACTORS OR THEIR EMPLOYEES, MAKES ANY WARRANTY, EXPRESSED OR IMPLIED, OR ASSUMES ANY LEGAL LIABILITY OR RESPONSIBILITY FOR THE ACCURACY, COMPLETENESS, OR USEFULNESS OF ANY INFORMATION, APPARATUS, PRODUCT OR PROCESS DISCLOSED; OR REPRESENTS THAT ITS USE WOULD NOT INFRINGE PRIVATELY OWNED RICH'TS. 
TABLE OF CONTENTS

Page Number

I. ABSTRACT

II. INTRODUCTION

III. ENGINEERING FEASIBILITY

IV. ECONOMIC FEASIBILITY

V. LEGAL CONSIDERATIONS AND

RESOLUTIONS OF PROBLEMS

VI. CONCLUSIONS AND RECOMMENDATIONS

VII. REFERENCES

VIII. APPENDICES
1

2

3

9

14

15

18

19 
I. ABSTRACT

This report addresses the feasibility of utilizing a low temperature geothermal

resource to heat the Polo High School and the community of Polo, consisting of 17 residential homes, 2 public school buildings, 5 commercial establishments, and the St. Liborius Church/School complex.

Depending upon the availability of a water use permit from the South Dakota Department of Natural Resources and the payback period required for this type of project, there is heat energy in the existing geothermal resource to heat the Polo High School or even the entire community of Polo.

The chemical analysis of the water indicates that any heat exchangers used should be stainless steel or thick-walled copper and piping should be plastic. An environmental assessment would be required to consider the disposal of geothermal fluid. 
GEOTHERMAL FEASIBILITY ANALYSIS II FOR POLO SCHOOL DISTRICT \#29-2

POLO, SOUTH DAKOTA

II. INTRODUCTION

Hengel, Berg \& Associates were retained by EG\&G Idaho, Inc., under Department of Energy funding to provide technical assistance in developing an appropriate scheme and cost analysis for utilization of geothermal heat energy by the Polo School District \#29-2. The primary purpose of the study was to determine the feasibility of utilizing a low temperature geothermal resource to heat the Polo High School. A secondary purpose that developed during the study was to evaluate the feasibility of developing a small geothermal water heating district for the entire community of Polo.

Information about the Polo High School building was obtained by a review of the plans for the building and an on-site inspection. The Polo High School building is a structure of approximately 12,000 square feet with an approximate volume of 220,000 cubic feet. The high school has a standard gymnasium with stage and locker rooms. In addition, there are five classrooms; three administrative offices, and related support facilities. The capacity of the in-place electrical heating system is approximately $600 \mathrm{MBH}$. Recently-added ceiling insulation reduced the calculated heat loss of the building to $481 \mathrm{MBH}$.

The basic construction of the building walls is 8 " concrete masonry units with the cores filled with loose insulation and a 2 " rigid insulation covered by 5/8" gypsum board on the interior. The upper 12 feet of the gymnsaium wall is of steel construction with $2 "$ fiberglass batt insulation and metal panels. The original roof construction is metal deck with $2^{\prime \prime}$ to $3^{\prime \prime}$ of rigid insulation. An additional $6 "$ to $9 "$ of insulation was recently added at the ceiling level.

There is an existing well in Polo. This well is owned by St. Liborius Church which is located across the steet from the high school building. The well is located approximately 700 feet from the high school building. The depth 
of the well is approximately 1,585 feet. We were advised that the flow rate is 100'gallons per minute with a pressure of 85 pounds per square inch and a temperature of 96 degrees F. The St. Liborius well provides all of the domestic water for the town of Polo, and it is used for heating the St. Liborius Church, School and Rectory.

A survey of the residential and commercial buildings in Polo was conducted by the Polo Superintendent of Schools, Mr. Walt Johnson.

The community of Polo consists of 17 residential homes (including 5 mobile homes), two public school buildings, five commercial establishments, and the St. Liborius Church/School complex.

\section{ENGINEERING FEASIBILITY}

A. Distribution System

1. Community Data: Climatological data available for the Polo area indicates that the outside design winter temperature is -20 degrees $F$. Based on an indoor temperature of 65 degrees F., it is estimated that tie peak seasonal demand, allowing some diversity, for the community of Polo would be approximately 2.5 times $10^{6}$ BTU per hour including the residential, commercial, and school buildings and the St. Liborius complex. The annual energy requirements based on 8223 degree days per year would be 5.4 times $10^{9}$ BTU. Any proposed water supply for a heating district would have to be sized to provide this capacity.

To serve the peak heating demand for the entire Polo community, a flow of approximately 140 gallons per minute of geothermal fluid would be required. This quantity is based on the assumption that an additional well would have a temperature of 96 degrees $\mathrm{F}$. The 140 gallon per minute requirement is based on a geothermal fluid temperature drop of 36 degrees $F$ and the use of ground water heat pumps. That drop is from the 96 degrees $F$ temperature at the well to an estimated 60 degrees $F$ temperature at the end of the system. A cascaded system would be required to extract the required amount of heat in four stages of approximately 
9 or 10 Degrees $\mathrm{F}$ geothermal fluid temperature drop each.

2. High School System: The types of electrical heating systems to be modified or replaced are as follows:

a. Electric unit ventilators.

b. Electric baseboard heaters.

c. Electric radiant glass heaters.

d. Electric unit heaters.

e. Gymnasium ventilating unit.

Because of size, diversity of use, and heating requirements, two different types of systems"are proposed for the Polo High School. The system proposed to provide heat to the gymnasium, stage and girl's locker room would be similar to a Westinghouse Templifier unit that would be used in conjunction with a hot water coil that would be installed in the existing gymnasium ventilating unit. The Templifier unit is a water-to-water heat pump type system where the heat energy from the geothermal fluid would be transfered to a treated system water. The terminal heating units would include the hot water coil in the existing ventilating unit and baseboard radiatiun units in the locker room-office area. The Templifier would have an expected COP of $\underline{4.5}$ for this installation application. The classroom and office area would be heated using a unit similar to the Friedrich geo-thermal heat pump. This unit is a water to air heat pump system. The heat from the geothermal fluid would be transferred to the air that is circulated into the rooms. This system would require duct work from the heat pump to the rooms being heated. The Friedrich geo-thermal heat pumps hve a peak COP of $\underline{3.77}$ and an average COP of $\underline{3.70}$, for the performance range which was used for this study.

To provide an amount of heat equal to the heat loss of $481 \mathrm{MBH}$, reduced to $408 \mathrm{MBH}$ (considering internal building diversity), a flow rate of 63 gallons per minute with a water temperature change of 13 degrees $F$ was selected. The reference to "internal building diversity" is that since there are a relatively large number of individual heating units in the building, not more than $85 \%$ of the units are expected to be heating at any one time. Other combinations of flow rate and temperature changes are possible. Each variation in elther the flow rate or temperature change affects the dollar value of the net 
energy savings. The operating flow rate and water temperature change selected match the manufacturer's recommended operating range of the heating equipment. COMPARISON OF ESTIMATED ENERGY

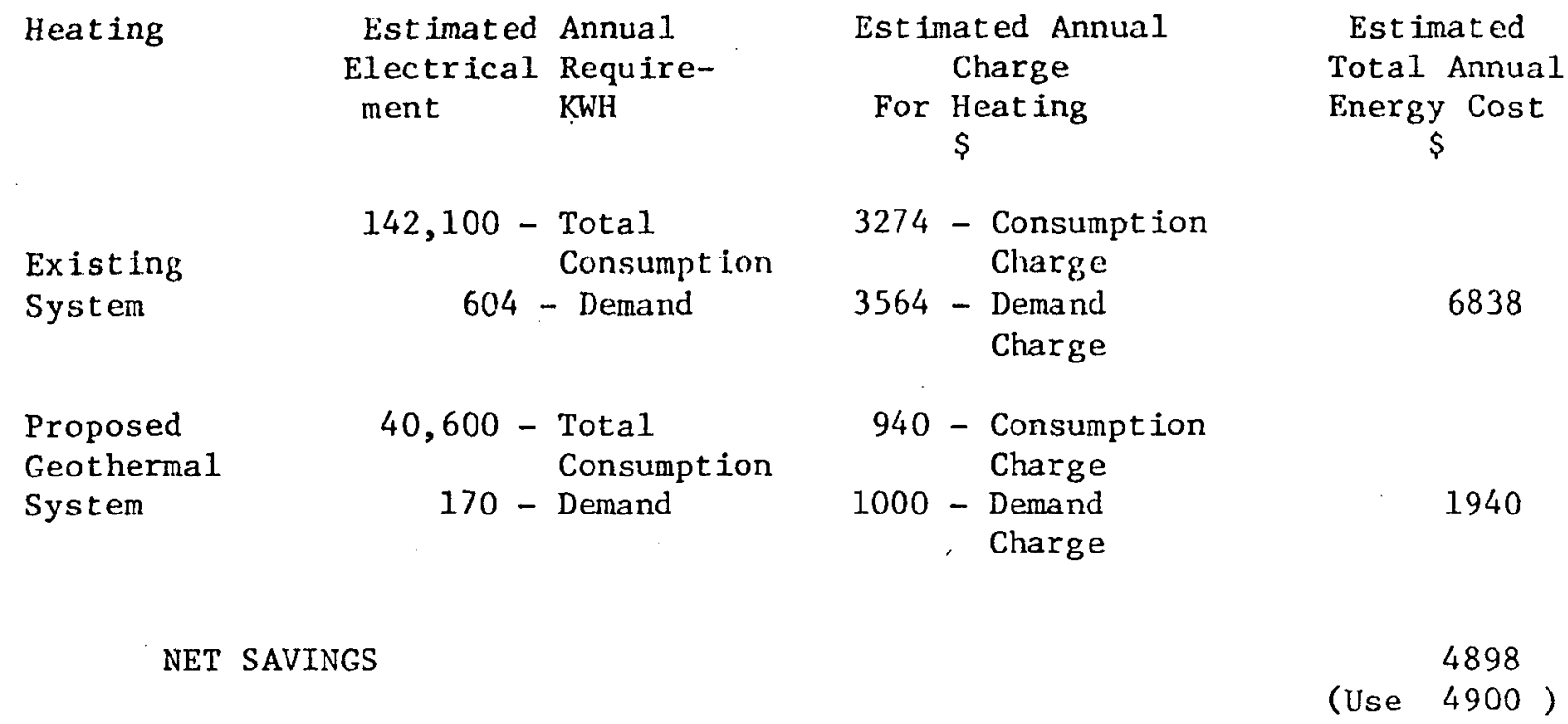

The electrical demand charge rate $=\$ 5.95 / \mathrm{KW}$.

The electrical consumption charge rate is as follows:

Large commercial: First $100 \mathrm{KWH}$ at $\$ .03 / \mathrm{KWH}$

Remaining $\mathrm{KWH}$ at $\$ .023 / \mathrm{KWH}$

Residential and small commerical: $\$ .051 / \mathrm{KWH}$

IABLL: L

A system of cascading the water was considered. This system would have the geothermal water flow through the Templifier system where approximately 13 degrees $F$ would be extracted. From there the geothermal water would flow through the water source heat pumps. Because the water source heat pumps would be receiving geothermal water that was 13 degrees $F$ cooler, the estimated value of the net energy savings would be approximately $\$ 600.00$ less than shown in Table 1 above.

Consideration was given to including hot water pre-heat coils in the High School system. In the office-classroom area, where water to air heat pumps would be used, it was found that there would typically be no reduction in heat pump sizing and, furthermore, the electrical power input requirements would be increased by $7.5 \%$ and the duct work would have to be increased in size, adding to the cost of the system. In addition, there would be further cost increase due to additional coils and piping. 
In the gymnasium, where a water-to-water heat pump would be used, the hotwater preheat coil in the air handling unit would have no direct effect on the sizing of the heat pump, and furthermore, electrical requirements for running the fan would be increased from 25 to $50 \%$.

The geothermal fluid would be plped to the school building and then through the heat pumps. If the existing well is used, the water would have to be placed into the city water system, since the St. Liborius well provides all of the domestic water for the town of Polo, as stated in the Introduction.

3. Heating District (For the entirc community): The types of electrical heating systems to be replaced or modified are as follows: residential: Baseboard Radiation commercial: Baseboard Radiation

The estimated annual electrical energy per residence that coverted to a heat pump would be approximately $6000 \mathrm{KWH}$. The estimated annual electrical consumption for heat energy with the existing electric heating systems is $21,000 \mathrm{KWH}$, per residence.

An alternative would be to use heat pumps which are more efficient at temperatures down to 40 degrees $F$. These units have a higher original cost. With this alternative approximately 90 gallons per minute of geothermal fluid would be required. This quantity could be supplied by the available resource. Thus, a new well would not have to be drilled for this alternative. However, it would be difficult to determine which owners would receive 40 Degrees $F$ water as opposed to 60 Degrees $\mathrm{F}$ water.

A survy of the Polo community indicates that of the approxinately 24 buildings which have potential for conversion to geothermal heating, nine are presently 
heated with electricity, eight are heated with propane, and seven are heated with fuel oil.

For the residential and commercial buildings, three different types of conversion equipment were considered:

a. Install a hot water coil in either the supply or return plenums of forced air furnaces.

b. Install a water source heat pump and connect it to the existing duct work system or provide a new duct work system.

c. Install a water to water heat exchanger for an existing hot water heating system.

of the above three types of conversion equipment, only the heat pump would provide the efficiency necessary to adequately heat the buildings with the low temperature geothermal fluid. The water temperature of 96 degrees $\mathrm{F}$ is too low for good heat transfer capabilities for either a coil in the plenum or using a heat exchanger.

B. Production System The options that were considered are as follows:

1. Utilize approximately 63 gallons per minute of water from the well owned by the St. Liborius Church to heat the high school building.

2. Drill a new well to provide water to heat the high school.

3. Drill a new well and utilize this well in conjunction with the St. Liborius well to heat the high school and the 23 residential and commercial buildings in Polo.

C. Disposal System

If a new well is drilled, the water would have to be piped to a satisfactory discharge location. For purposes of this report, it is assumed that this water could be discharged in the same area where the excess water from the 
St. Liborius well is now discharged.

D. Feasibility

Determination of the most feasible system concepts would be carried out by assessing the following:

1. Cost.

2. Efficiency.

3. Payback period.

4. Number of building owners willing to make the conversion.

5. Water rights.

6. Environmental impact.

E. Schematics

The following schematics are included in this report:

Fig. 1 Utilization of Existing Well

Fig. 2 New Well

Fig. 3 Joint Utilization of Existing Well and New Well

F. Domestic Water Heating

At present the domestic water for the High School is heated by two electric water heaters: one is a $48 \mathrm{KW}$ - 120 gallon water heater, the other is a $1.5 \mathrm{KW}-30$ gallon water heater.

Geothermal water could be used to preheat the domestic water and thus reduce the electrical energy requirements for heating domestic water.

There are 53 students enrolled at Polo High School, and there are 10 staff members. In addition, 24 junior high students use the building on a part-time basis.

The hot water demand for that enrollment would be approximately 120 gallons per day. Without geothermal water preheat, the energy requirement would be approximately $5300 \mathrm{KWI}$ per year or $18 \times 10^{6}$ BTU per year.

With geothermal water preheat the energy requirement would be reduced to approximately $3200 \mathrm{KWH}$ per year or $10.8 \times 10^{6}$ BTU per year. 
IV. ECONOMIC FEASIBILITY

A. System Economics using the water from St. Liborius We11

Water piped to the High School Building, through the heating system and

then into the domestic water distribution of the Polo community.

Pipe and Installation (Approximately 700 feet supply \&

700 feet return)

15,000

Building Heating System Conversion

65,000

Contingency and Engineering

Total Estimated Capital Expenses

$\frac{15,000}{\$ 95,000}$

B. System Economics using water from a new well.

Water piped from a new well to the High School Building and then to a

discharge location within one thousand feet of the building.

New Well (Estimate from Huron Drilling)

25,000

Well House

10,000

Pipe \& Installation

10,000

Building Heating System Conversion

65,000

Contingency \& Engineering

Total Estimated Capital Expenses

$\frac{22,000}{\$ 132,000}$

If a new well and the St. Liborius well are used in an integrated system, part of the surplus would be put back into the polo domestic water system and the balance discharged to the present discharge point.

C. System Economics using water from the existing St. Liborius well

and a new well to heat all of the buildings in the Polo Community.

New Well

Well House

High School System Conversion

Residential Heating System Conversion (17 Residences)

Commercial Heating System Conversion (Includes old High School)

Distribution System (Pipe, etc.)

Contingency \& Engineering

Total Estimated Capital Expenses
25,000

10,000

65,000

108,000

60,000

80,000

$\frac{63,000}{411,000}$

The cost breakdown for a typical residential conversion to a heat pump; 
using the geothermal. water resource, 1s as follows: (1981 prices)

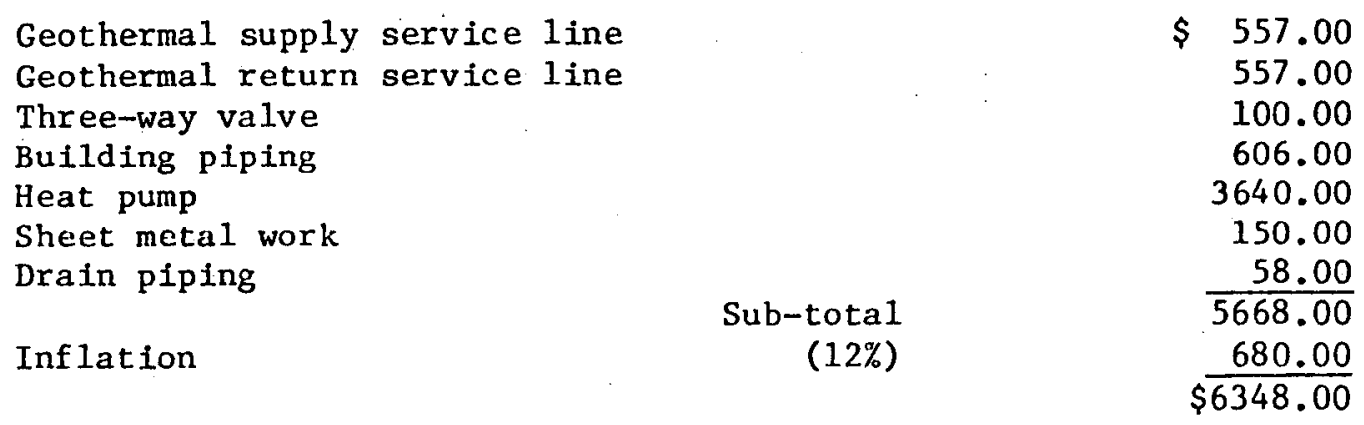

D. Domestic Water Economics; Installation of Preheat System:

Two Nuw Preheat Colles

$\$ 1660.00$

Piping

1010.00

Controls

400.00

Contingency \& Engineering

Total Estimated Capital Expenses

$\frac{710.00}{\$ 3780.00}$

E. Heating/Air Conditioning

The water source heat pumps can be used for either heating or air

conditioning without adding construction costs. Savings for air conditioning

were not used in the economic studies of this report.

F. Rights of Way and Leases

It is assumed that rights of way costs, in this small community, whether

just the high school is heated, or if a heating district is formed to serve the

entire community, would be non-existent, since either plan would benefit the entire

community and the distribution system would be installed in the public streets

rather than on private property.

If the St. Liborius well is used to heat the high school or part of the

community, there would be an estimated 99-year lease cost of $\$ 1,400.00$.

G. Energy and Monetary Savings

1. Using the St. Liborius well to heat the Polo High School:

$\begin{array}{llrl}\text { Energy Savings } & = & 101,500 \mathrm{KWH} / \text { year on consumption } \\ \text { Energy Savings }= & 434 \mathrm{kWH} / \text { year on demand } \\ \text { Monetary Savings }= & \$ 2,334 \text { year on consumption } \\ \text { Monetary Savings }= & \$ 2,582 \text { year on demand } \\ \text { Total Monetary Savings } & =\quad 4916=\$ 4900 / \text { year }\end{array}$

Note: This assumes that $0 \& M$ costs are held constant. 
2. Using a new well to heat the Polo High School:

Same as Item 1 above.

3. Using water from the St. Liborius well and a new well to heat the entire Polo Community:

Energy Savings (assuming conversion to heat pumps):

(Note: Electric consumption based on: $11,600 \mathrm{BTU} / \mathrm{KWH}$ )

Note: Assumed $\mathrm{COP}=3.5$

Net Savings

High School: $\quad 101,934 \mathrm{kWH} /$ year $1.18 \times 10^{9}$ BTU/year

Residences:

6 with, electric heat

5 with fuel oil

6 with propane

$91,218 \mathrm{KWH} /$ year $1.06 \times 10^{9} \mathrm{BTU} /$ year

$2,590 \mathrm{ga} 1 /$ year $0.02 \times 10^{9} \mathrm{BTU} /$ year

$4,512 \mathrm{gal} /$ year $0.024 \times 10^{9} \mathrm{BTU} /$ year

Commercial:

2 with electric heat

1 with fuel oil

2 with propane

$56,978 \mathrm{kWH} /$ year

$0.66 \times 10^{9} \mathrm{BTU} /$ year

$981 \mathrm{gal} /$ year $0.007 \times 10^{9}$ BTU/year

$2,850 \mathrm{gal} /$ year

$0.014 \times 10^{9}$

BTU/year

Total Energy Savings

$$
=
$$

$2.97 \times 10^{9}$

BTU/year

Monetary Savings: (Net after deducting cost of heat pump operation)

High School:

$\$ 4,900 /$ year

Residences:

6 electric
5 fuel oil
6 propane

$4,650 /$ year

$1,030 /$ year

$1,180 /$ year

Commercial:

2 electric

1 fuel oil

2 propane

$2,910 /$ year

$390 /$ year

740 /year

Total Monetary Savịngs

$\$ 15,800 /$ year

4. Domestic water preheat:

The energy savings using geothermal water to preheat the domestic water would be $2100 \mathrm{KWH}$ per year or $7.2 \times 10^{6}$ BTU per year (See Section III F). 
The monetary savings on the $2100 \mathrm{KWH}$ would be $\$ 55 /$ year.

H. Payback SPP =

\section{System Cost}

(Simple Payback Period)

Energy Cost Savings

1. Using the St. Liborius well to heat the Polo High School:

$\mathrm{SPP}=\frac{\$ 95,000}{\$ 4,900}=19.4$ years

If Inflation equals the rate of interest on borrowed money, payback period = 19.4 years. If inflation is less than interest on borrowed money, the length of payback period will increase. If inflation is more than interest on borrowed money, the length of payback perlod will decrease.

2. Using a new well to heat the Polo High School:

$$
\mathrm{SPP}=\frac{\$ 132,000}{\$ 4,900}=26.9 \text { years }
$$

3. Using water from the St. Liborius well and a new well to heat the entire Polo community:

SPP $=\frac{\$ 411,000}{\$ 15,800}=26.0$ years

4. Domestic water preheat:
SPP $=$
$\frac{\$ 3780}{55}$
$=\quad 68.7$ years 
I. Amortization Scheme for Polo High School Conversion

The amortization costs (using the existing we11), at an interest rate

equal to the local school bond interest rate of $5 \%$ with no allowance for inflation, are shown below for various life cycles:

\begin{tabular}{cccc} 
Life Cycle (years) & Annual Dobt Costs & $\begin{array}{l}\text { Annual } \\
\text { O\& } \& \text { Costs }\end{array}$ & $\begin{array}{l}\text { Annual. } \\
\text { Total Cost }\end{array}$ \\
\cline { 2 - 3 } 30 & 6180 & 1940 & 8120 \\
50 & 5204 & 1940 & 7144 \\
75 & 4875 & 1940 & 6815 \\
100 & 4786 & 1940 & 6726
\end{tabular}

TABLE 2

It is evident from the above amortization table that the annual energy

monetary savings of $\$ 4900$ will not cover the debt amortization and 0 \& M costs, even in a 100-year life cycle.

J. Simple Payback with Fuel Cost Escalation for Polo High School 20-year Time Period

Geothermal
System

$0 \%$

(Thousand Dollars)
$15 \%$ Fuel Cost Inflation $5 \% \quad 10 \%$

19

19

Cost

95

19

19

363

922

2242

Cost

39

137

156

382

941

2261

SPP-years

(Simple Payback Period)
19.4

7.3

2.9

1.2

TABLE 3 


\section{LEGAL CONSIDERATIONS AND RESOLUTIONS OF PROBLEMS}

A major obstacle with all of the options discussed in this report is the problem of obtaining a water right to use the water for heating. From previous action by the South Dakota Department of Natural Resources regarding water from the formations in the Polo area, it appears that the first step in the activity sequence for utilization of geothermal resources is to obtain a water right. This must be accomplished before any further consideration can be given to using this geothermal resource. We were advised that the South Dakota Department of Natural Resources does not have any record that the St. Liborius well has a water right or a permit for the well. Apparently that well was drilled prior to the requiring of permits or the permit has been lost.

We were also advised that the wells drilled into the water bearing formations in the Polo area are limited to domestic use only. The water pressure in this formation has been dropping at the rate of 1 foot of head per year. Because of this drop, the South Dakota Department of Natural Resources has restricted the usage of this formation.

The time required for submittal of application and action by the Department of Natural Resources would be between two to four months depending on the time when the application is submitted and the date when applications are reviewed by the commission. 


\section{CONCLUSIONS AND RECOMMENDATIONS}

\section{A. Conclusions}

There is heat energy in the water from the St. Liborius well that could be economically extracted and utilized in heating the Polo School. The technology and equipment are available; off the shelf units can be used.

If no consideration is given to the value of money or if the inflation rate equals the interest rate, the utilization of the water from the St. Liborius well has a favorable payback. The payback period becomes even more favorable when compared to a $20 \%$ annual increase in the electrical energy costs. At a $20 \%$ per year increase in electrical energy costs the estimated value of net energy savings would increase from $\$ 4,900$ per year to over $\$ 10,000$ per year in 4 years. Other sources are projecting an increase in electrical costs at a rate of $8 \%$ to $10 \%$ per year compounded for the next 7 to 8 years. This would increase the annual savings to approximately $\$ 9,000$. With an eleatrical energy cost increase of $8 \%$ per year compounded the simple payback would be approximately 12 to 13 years. With a simple payback of less than 15 years the use of the water from the St. Liborius well should be given further consideration.

Applying the same rate of increase to electrical energy as above, the simple payback period for a system with a new well would be between 16 and 17 years. This payback period is slightly above the standard 15 year payback period. However, consideration should be given to this as an alternate design approach.

The simple payback period for the heating district would also be shortened when the above cost of electrical energy is used. The heating district becomes more complex because of the involvement of more people. There is also a greater diversity of types of structures. We would anticipate that initially the 5 mobile homes would not be converted and that less than half of the remainder of the buildings would be converted during the first year or two. We would estimate that it would take 
over 5 years before all of the buildings in the Polo community were on the geothermal water system. At this time the heating district appears to be marginal. However, if the school district elects to drill its own well, provisions in the piping at the school should be made to expand into a heating district. The added cost could be assesssed to the homes that do connect to the system in the future. Unless there are several homes in a cluster that are willing to make the conversion to geothermal heat, the cost of the distribution system makes the conversfon too $\cos t y$.

lirom the water chemistry it appears that the material used in the system should be either stainless steel or thick walled copper for the heat exchangers and plastic for the pipe. See Appendix A for a copy of the water analysis.

\section{B. Recommendations}

The first step in the sequence of activity needed to utilize the geothermal fluid for heating is to obtain a water use permit from the South Dakota Department of Natural :Resources.

After the permit has been obtained either to use the St. Liborius well or to drill a well, an environmental assessment should be prepared. The primary factor to be considered in the environmental assessment is the disposal of geothermal fluid and its effects on the ground. From the analysis of the water, it appears that the water is high in salts. This could have some adverse effect on the ground depending on the possibility of diluting this water with storm run-off water. The environmental assessment would take one to three months.

After all approvals have been obtained for discharge of the water, the design and preparation of construction documents could begin. Depending on the total scope of the project, that is whether the project includes only the school or if it also includes a heating district, the design time would be between two and three months. 
- The next phase of the project would then be advertising and obtaining bids for the construction of the project. With favorable bids, construction could proceed. Allowing time for delivery of materials, the construction could take from four to six months.

The economic analyses made in this report were based on certain assumptions of operating conditions. The actual results may vary because of different operating conditions over which we do not have any control.

The following is a time-based development activity chart:

\section{PROJECT MILESTONE CHART}

\section{Activity}

1. Approval of Technical Assistance Report (Geothermal Feasibility Analysis)

2. Obtain Water Use Permit

3. Environmental Assessment

4. Design Time

5. Bidding Time

6. Construction
Target Completion Date (Mo.-Day-Year)

$4-30-82$

$8-31-82$

$11-30-82$

$2-28-83$

$4-30-83$

$10-31-83$ 
VII. REFERENCES

The reference materials/sources used for this study are as follows:

1. Polo High School plans, dated: February 7, 1972.

2. Residential/Commercial building: survey conducted by: the Polo Superintendent of Schools, Mr. Walt Johnson, dated November 24, 1981.

3. Written and verbal communication with the Polo Superintendent of Schools.

4. Letter from Ree Electric Cooperative, dated December 3, 1980.

5. ASHRAL 1981. Handbook of findamentals.

6. Water Analysis Report from the South Dakota: School of Mines \& Technology, dàted February 5, 1981.

7. Climatological data from the Huron, S.D., area from NOAA.

8. Data fxom Huron Drilling on the existing well, dated April 18, 1980.

9. Westinghouse Technical Manual on Templifier Unit, dated September, 1979.

10. Friedrich. Heat Pump Manual, dated January 1980.

11. 1981 Means Cost Data Manua1.

12. Communication with the South Dakota Office of Energy Policy.

13. Economic Analysis text by N. D. Barish, dated 1962. 
VIII. APPENDICES

Appendix A: Water Analysis Report

Appendix B : Schematics

Fig. 1. Utilization of Existing Well

Fig. 2. New Well

Fig. 3. Joint Utilization of Existing Well and New Well 
APPENDIX A

ERGINBERING \& MINING EXPERIMENT BTATION

of the

BOUTA DAXOTA SCHOOI OF MANES \& TECHXOX.OGY

\section{REPORT OF ANALYSIS}

Rapid City, S. D., 5 February 1981, 19....

Mr...... Henge1, Berg, and Associates

115_Saint Joseph Street2_Rapid City

The sample of Water--Polo

received from you has been analyxed and the results obtained are as follows:

Certificate No. 801-951

Your semple No.

\begin{tabular}{|c|c|c|c|}
\hline SUBSTANCE & $\mathrm{mg} / \mathrm{L}$ & SUBSTANCE & $\mathrm{mg} / \mathrm{L}$ \\
\hline \multirow[t]{2}{*}{ Dotal Dissolved Solids } & 2268 & Calciun (Ca) & 417.0 \\
\hline & & Magnesium (Mg) & 102.1 \\
\hline \multirow[t]{3}{*}{ Total Suspended Soljde } & & Sociium (Na) & 51.7 \\
\hline & & Potassium (K) & 27.4 \\
\hline & & $\operatorname{Iron}(\mathrm{Fe})$ & 5.5 \\
\hline Totel H1:"ines: & 1460 & Mangemese $(\mathrm{Mn})$ & \\
\hline Carboncte Herciness & $1040^{\circ}$ & & \\
\hline \multirow[t]{2}{*}{ Non-Carbonate Hardress } & 420 & & \\
\hline & & Chloride (Cl) & 63.5 \\
\hline $\mathrm{pH} \quad \cdots \quad 6.5$ & & Sulfate $\left(\mathrm{SO}_{4}\right)$ & 1120 \\
\hline Alkalinity (Phenolph'n) & & Silica $\left(\mathrm{SiO}_{2}\right)$ & \\
\hline \multirow[t]{2}{*}{ Alkalinity. (Nét. Orange) } & .131 .2 & Nitrate $(N)$ & \\
\hline & & Orthophosphate $\left(\mathrm{PO}_{4}\right)$ & \\
\hline Turbidity (J.U.) --. & & Total Phosphate $\left(\mathrm{PO}_{4}\right)$ & \\
\hline Spu.e. Gonductance -- & & & \\
\hline
\end{tabular}

REMARKS:

The Engineering and Mining Exp riment Station naumes no responsibility, in to the ounce of the nbove nsmples.

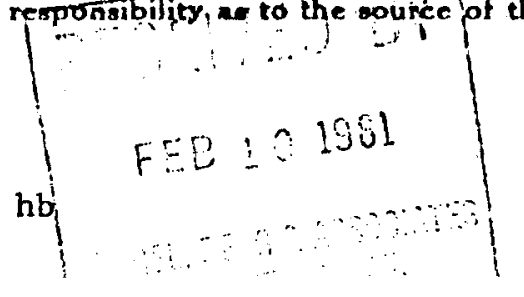

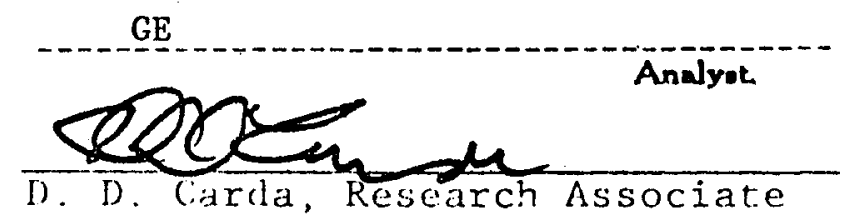


APPENDIX B

Fig. 1 Utilization of Existing Well

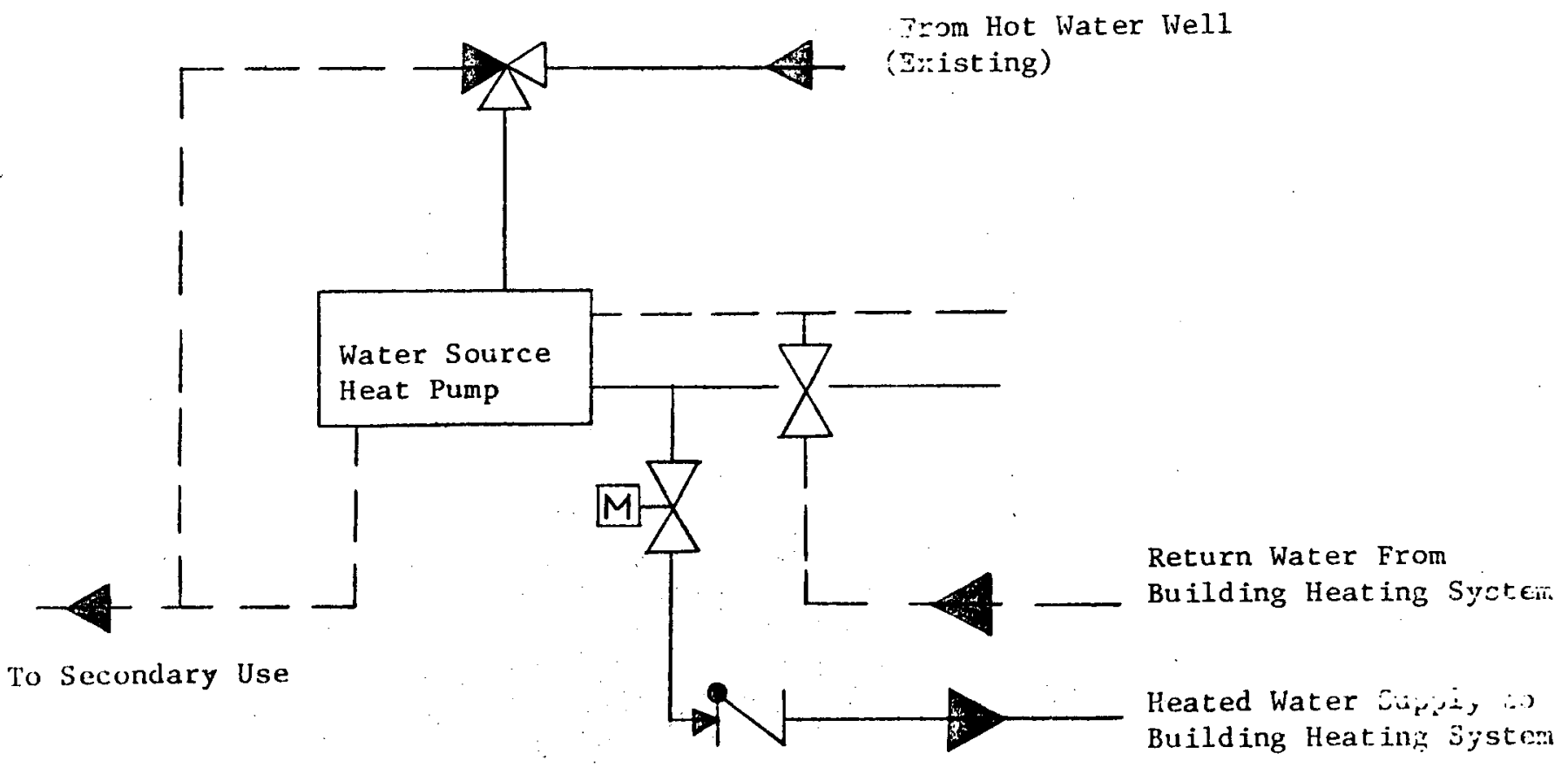




\section{APPENDIX B}

Fig. 2 New Well

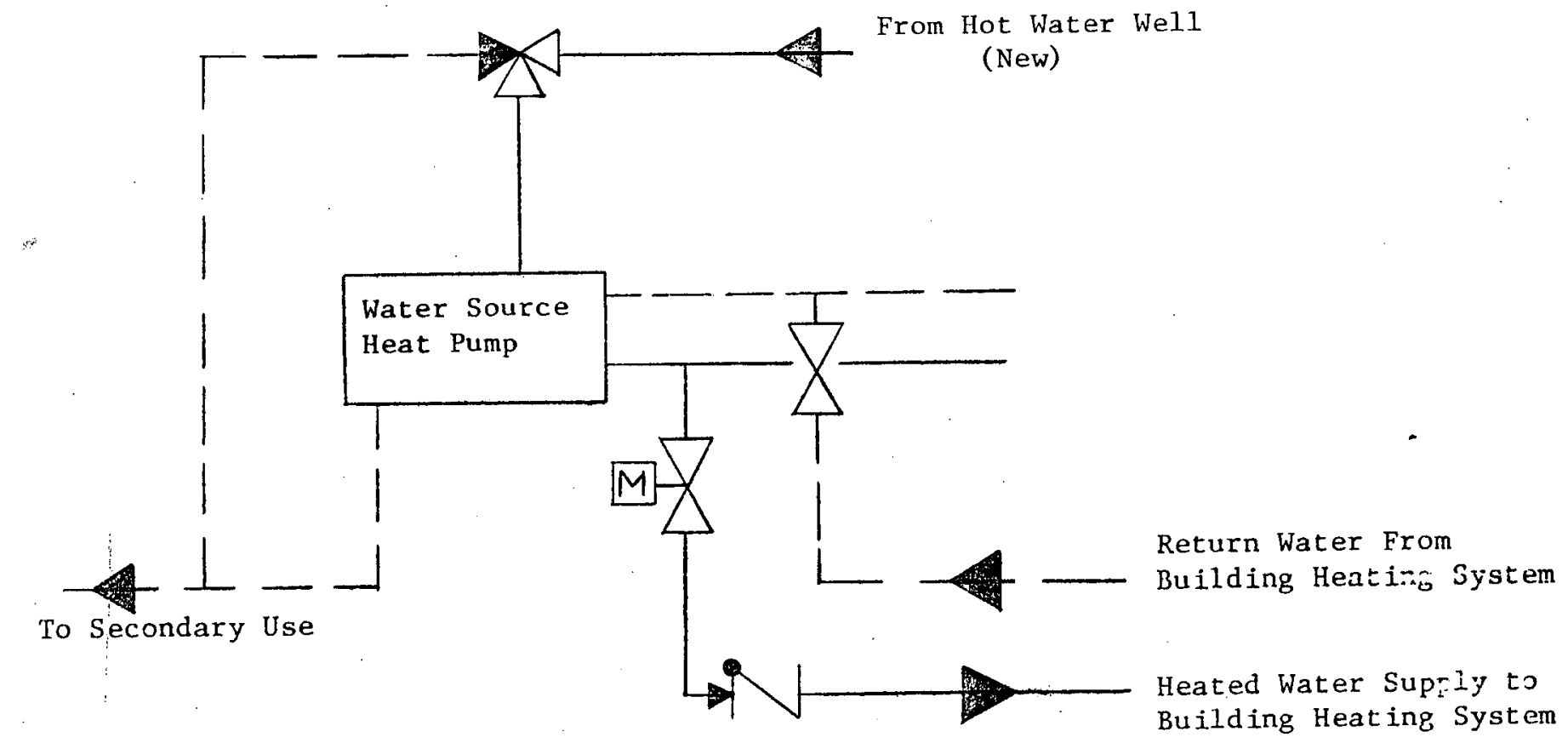

, 


\section{APPENDIX B}

Fig. 3. Joint Utilization of Existing and New Wells

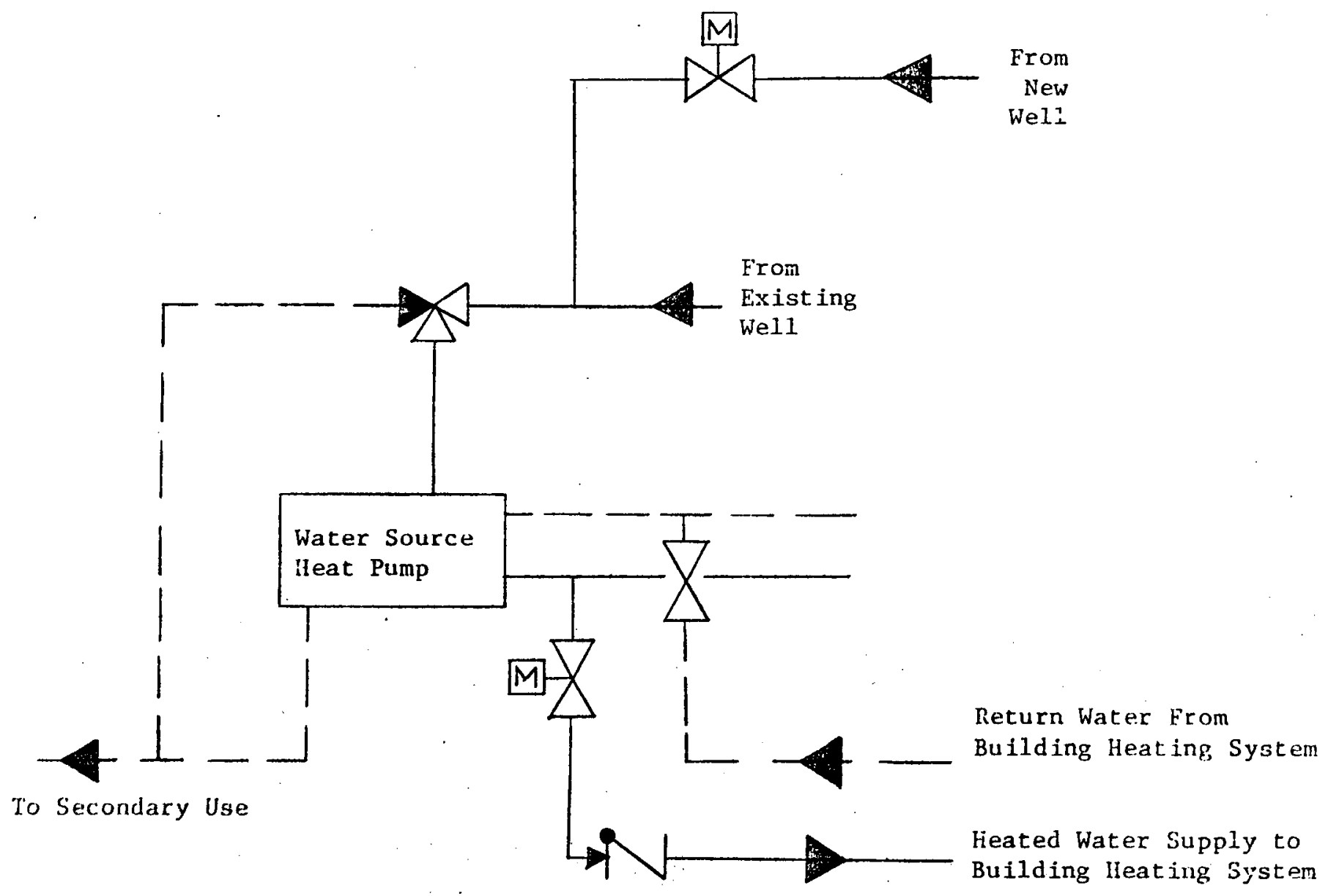

